\title{
Physical and Mechanical Properties of Sustainable Hydraulic Mortar Based on Marble Slurry with Waste Glass
}

\author{
Bartolomeo Megna ${ }^{1,2}{ }^{(0)}$, Dionisio Badagliacco ${ }^{1}$, , Carmelo Sanfilippo ${ }^{1, *}$ and Antonino Valenza ${ }^{1}$ \\ 1 Department of Engineering, University of Palermo, 90128 Palermo, Italy; bartolomeo.megna@unipa.it (B.M.); \\ dionisio.badagliacco@unipa.it (D.B.); antonino.valenza@unipa.it (A.V.) \\ 2 INSTM Research Unity of Palermo, 90128 Palermo, Italy \\ * Correspondence: carmelo.sanfilippo01@unipa.it
}

Citation: Megna, B.; Badagliacco, D.; Sanfilippo, C.; Valenza, A. Physical and Mechanical Properties of Sustainable Hydraulic Mortar Based on Marble Slurry with Waste Glass. Recycling 2021, 6, 37. https:// doi.org/10.3390/recycling6020037

Academic Editors: José Neves and Ana Cristina Freire

Received: 8 April 2021

Accepted: 4 June 2021

Published: 9 June 2021

Publisher's Note: MDPI stays neutral with regard to jurisdictional claims in published maps and institutional affiliations.

Copyright: (c) 2021 by the authors. Licensee MDPI, Basel, Switzerland. This article is an open access article distributed under the terms and conditions of the Creative Commons Attribution (CC BY) license (https:// creativecommons.org/licenses/by/ $4.0 /)$.

\begin{abstract}
This paper aims to propose and characterize a sustainable hydraulic mortar entirely obtained by the reuse of waste materials, with marble slurry coming from quarries in the northwestern Sicily and glass powder coming from a waste collection plant in Marsala (Province of Trapani). The first was used as raw material to produce the mortar binder by a kilning and slaking process, while the second was used as a pozzolanic additive. The chemical and morphological characterization of the marble slurry was done by XRD, FTIR, STA and SEM analyses. Glass powder was analyzed through particle size distribution measurements, XRD and standard pozzolanic tests. Hydraulic mortars constituted by slaked lime from kilned marble slurry and waste glass powder (LGS) were prepared beside commercial Natural Hydraulic Lime (NHL) based mortars (NGS) and air-hardening lime (LSS)-based mortars. Mechanical and absorption properties of the mortars were investigated as a function of the grain size of the glass powder by means of three-point bending and compressive strength tests, capillary uptake, helium pycnometry and simultaneous thermal analysis. The results demonstrated that the formulation LGS exhibits significantly improved mechanical and absorption properties compared to air-hardening mortars (LSS). It confirms the possibility of producing a more sustainable hydraulic mortar exclusively from waste materials for civil engineering.
\end{abstract}

Keywords: hydraulic mortars; waste materials; pozzolanic aggregates; recycled glass; marble slurry

\section{Introduction}

In the last decades, a considerable amount of research has concerned the use of waste marble [1-7] and waste glass powders [8-18], separately, as additives to improve the physical and mechanical properties of mortars and concretes. However, the possibility to use these two materials simultaneously to produce a new sustainable binding system has not been investigated to date.

Waste materials causes a tremendous effect on air, water, vegetation, animals, human health and living conditions [19]. Overall, it is predicted that the 12 billion tons of waste produced in 2002 (with 11 billion tons corresponding to industrial waste) will increase up to 25 billion tons in 2025 [20,21]. It is evident that the increase will pose a tremendous threat to environmental health in the absence of appropriate measures.

It is well known that Portland cement production is one of the most environmental unfriendly process due to its high working temperature $\left(1400-1500{ }^{\circ} \mathrm{C}\right)$ and the massive consumption of raw materials such as limestone and clay. Cement production causes a considerable amount of greenhouse gas emissions both by carbonate decomposition and by fossil fuels combustion to heat the kiln. The carbon dioxide to Portland cement weight ratio is close to 1:1 [22]. Moreover, the extraction of raw materials used for its production is further an environmental issue and source of $\mathrm{CO}_{2}$ emissions [23].

Marble slurry has to be disposed as hazardous industrial waste [24], according to the limits established by Italian law. If not properly disposed, it is generally poured into riverbeds, damaging aquatic populations. Since slurry mainly consists of $\mathrm{CaCO}_{3}$, it could 
be used as raw material for lime production. This would result in a lowering of the environmental impact of lime production due to the reduction of energy consumption for the extraction and grinding of the raw materials, which contributes to more than $10 \%$ of the $\mathrm{CO}_{2}$ emissions associated with binder production $[25,26]$.

The issue of management and disposal of sludge from the exploitation of carbonatic rocks is of increasing interest. In particular, in the area of Custonaci (Province of Trapani), the marble quarries produce approximately 200,000 tons/year of sawing mud, which is mostly disposed of by filling the same quarries, demonstrating the vast abundance of waste, and encouraging its possible use on an industrial scale [24].

The literature is also focused on the possible use of waste marble for production of clay bricks $[8,27-29]$.

Glass is a recyclable material that can be indefinitely recycled [9]. Even though a portion of this glass is easily recycled in the glass manufacturing industry, not all used glass can be recycled into new glass because of impurities, cost or mixed colors. Therefore, several decades ago, research was started to investigate the possibility of using waste glass in concrete production [18]. As noted by [10,11], waste glass can be used for many applications, such as the production of binders such as a siliceous aggregate for cement and concretes. Refs. [12,13] used glass powder from flat glass waste as pozzolanic material in the preparation of hydraulic limes or hydraulic mortars. According to [14], the amorphous silica $\left(\mathrm{SiO}_{2}\right)$ reacts with the portlandite generated during cement hydration and forms gels of calcium silicate hydrate (C-S-H). The effect of glass grain size incorporated into cement-based products was investigated by [30], who verified that fine glass powders improve the properties of concrete, while coarse aggregates are generally harmful. Ref. [31] and described the preparation of lime mortars in which the sand was replaced by crushed glass and calcium carbonate aggregates. The pozzolanic properties of the glass are first notable at particle sizes below $300 \mu \mathrm{m}$ [32]. It was argued by [33] that under $100 \mu \mathrm{m}$, the glass might exhibit higher pozzolanic reactivity compared to fly ash at low percentages of cement replacement after 90 days of curing. Previous studies observed a strong reaction between alkali materials in the cement and reactive silica, commonly referred to as the alkali-silica reaction (ASR). The grain size of the glass powder may influence ASR expansion. However, different authors claimed controversial results with ASR expansion increases [34] or decreases [35] with the fineness of the particles.

This paper highlights the possibility of using waste marble slurry as raw material to produce calcitic lime, and waste glass powder as a pozzolanic aggregate to produce a hydraulic binder entirely based on waste materials. Since the size of the particles strongly influences waste glass reactivity, three different grain size distributions were investigated. Mechanical and absorption properties of the new ecocompatible hydraulic binding system were compared with air-hardening lime and natural hydraulic lime. The experimental results provide evidence that the proposed hydraulic mortars can be a sustainable alternative to cement or natural hydraulic lime-based mortars, especially for nonstructural purposes.

\section{Materials and Methods}

\subsection{Characterization of Raw Materials and Products}

The raw materials used in this work came from two different sources of waste. Limestone slurry came from Custonaci (Province of Trapani), northwestern Sicily, basin quarries and resulted from the sawing-cooling system and the polishing system of limestone blocks. The amount of slurry produced in this site is around $2 \times 10^{5}$ tons/year [24]. Quicklime was obtained by kilning the marble slurry in a muffle furnace at $900{ }^{\circ} \mathrm{C}$ for $24 \mathrm{~h}$. Slaked lime was obtained by mixing quicklime and distilled water in a ratio of 1:2.5 by weight. After ten days an almost complete conversion of Calcium oxide to calcium hydroxide occurred and, hence, mortars were manufactured. The waste glass powder was provided by a selective waste collection site located in Marsala (Province of Trapani) operated by Sarco S.r.l. Finally, common river sand, consisting mostly of quartz with traces of biotite and feldspar, was used as aggregate of the mortars. 
The characterization of raw materials and products was made by means of X-Ray Diffractometry (XRD), Simultaneous Thermal Analysis (STA), Low Vacuum Scanning electron microscopy (SEM) with Energy Dispersion X-Ray Spectroscopy (EDS) and Fourier Transformed Infrared Spectroscopy (FTIR). Grain size distribution of glass powder was evaluated using standard sieves with a kilogram of glass powder.

According to the supplier, the granulometric range of the used sand was from 0.125 to $5.6 \mathrm{~mm}$.

XRD analysis was performed with a Panalytical Empyrean Diffractometer equipped with a PixCel $1 \mathrm{D}$ detector with $\mathrm{Cu}$ Ka radiation in the $2 \theta$ range 6-60.

Simultaneous Thermal Analysis was conducted in a Netzsch Jupiter F1 STA 449, in the range $30-1000{ }^{\circ} \mathrm{C}$ to evaluate the pozzolanic behavior of the glass powder [36].

The ESEM used in this work was a FEI Quanta 200 FEG coupled with EDS elemental analysis. The observation was performed using a low vacuum mode in order to analyze the samples without any further preparation.

FTIR spectroscopy was performed on a Shimadzu FTIR 8000, in the wavenumber range $400-4000 \mathrm{~cm}^{-1}$ with a $4 \mathrm{~cm}^{-1}$ spectral resolution. In order to obtain information on the organic compounds, the latter was extracted by submerging marble slurry in different suitable solvents, i.e., acetone and ethylic alcohol, and after an acid attack with a $5 \%$ by weight solution of hydrochloric acid. In both cases, the solid phase was mixed with reagent grade potassium bromide in a 1/100 weight ratio.

Pozzolanicity tests (according to UNI 11471, January 2013 [37]) were performed to establish the pozzolanic activity of each selected range of grainsize glass powder:

- $\mathrm{D}<125(\mu \mathrm{m})$.

- $125<\mathrm{D}<210(\mu \mathrm{m})$.

- $350<\mathrm{D}<500(\mu \mathrm{m})$.

Finally, thin sections of mortars were observed by optical microscopy to identify the presence of reaction borders.

\subsubsection{Waste Glass Powder}

The grain size distribution of the glass powder coming from the recycling plant is shown in Table 1. A significant percentage of the glass powder had diameters greater than $500 \mu \mathrm{m}$.

Table 1. Grain size distribution of glass powder.

\begin{tabular}{cc}
\hline Sieve Passing Diameter $[\mu \mathrm{m}]$ & Percentage Weight Retained [\%] \\
\hline 500 & 36.2 \\
\hline 350 & 11.4 \\
\hline 210 & 19.3 \\
\hline 125 & 10.3 \\
\hline 53 & 20.2 \\
\hline 0 & 2.3 \\
\hline Loss on Measurement & 0.3 \\
\hline
\end{tabular}

This result suggests the benefit of grinding the glass powder to increase the amount of smaller particles fraction characterized by higher reactivity [36,38].

The X-Ray test shown in Figure 1 (above) confirms the amorphous nature of the glass powder, mainly consisting of silicon, calcium and sodium oxides, as also highlighted by EDS analysis shown in Figure 1 (below). The same composition was also obtained by [39] who highlighted the possibility of glass powder acting as a pozzolanic or even a cementitious material. 

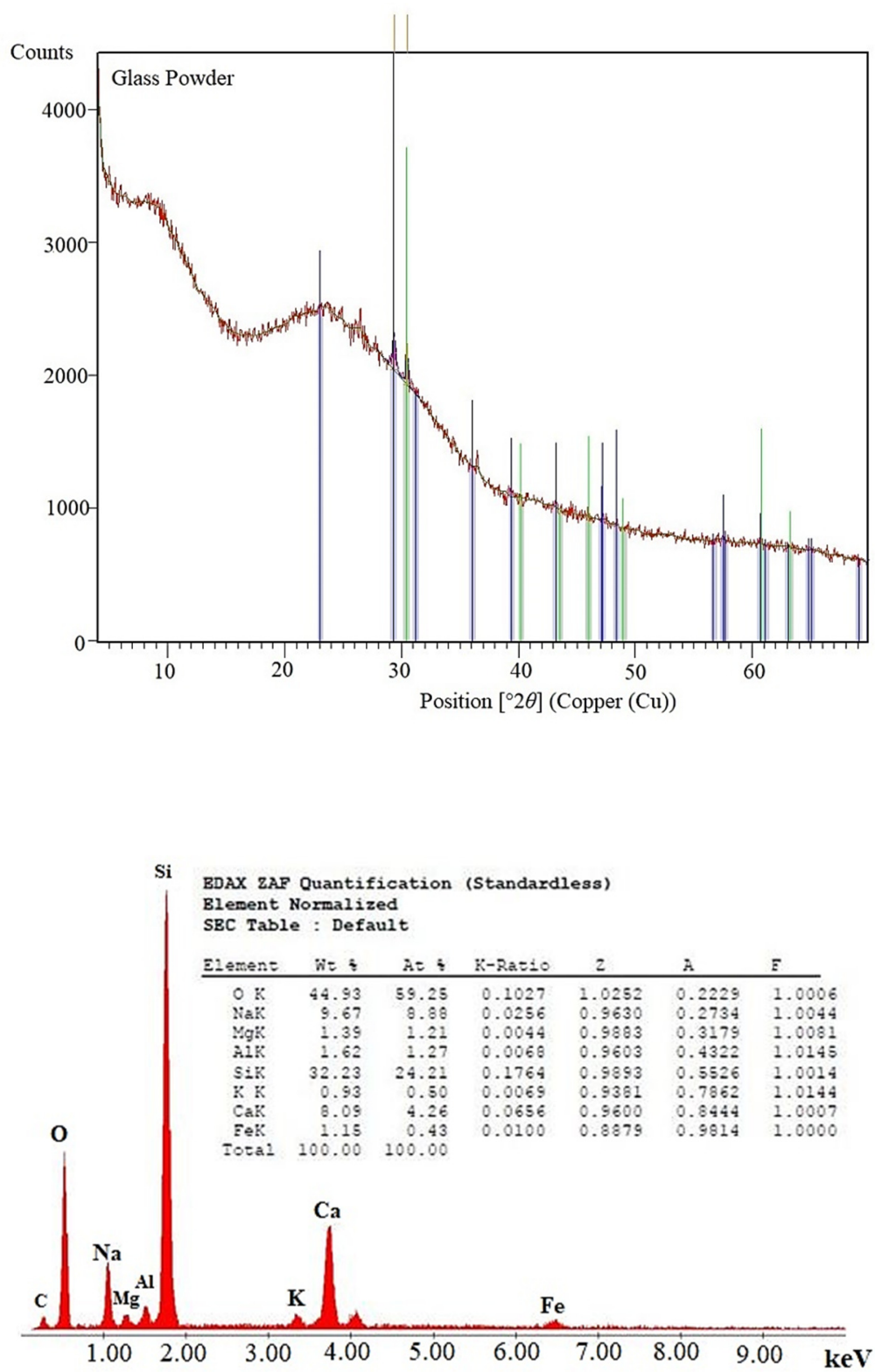

Figure 1. X-Ray pattern of glass powder (above); elemental Analysis of the glass powder (below).

The SEM micrographs in Figure 2 show as-received waste glass powders and ground waste glass powders, highlighting their angular shape.

The results of pozzolanic activity tests are shown in Figure 3.

From Figure 3, it is evident that each glass grain size showed pozzolanic behavior after 8 days. After 15 days, finer grain sizes exhibited higher reactivity, while coarser powders had lower reactivity as indicated by the small distance of the representing point from the equilibrium curve. This result is in accordance to that obtained by [33] who recorded a higher pozzolanic reactivity of fine glass powders below $100 \mu \mathrm{m}$ compared to fly ash. According to these considerations, mortars with coarser glass grain sizes were prepared using a grain size distribution from 210 to $350 \mu \mathrm{m}$ instead of 350 to $500 \mu \mathrm{m}$ as in pozzolanic tests.

\subsubsection{Marble Slurry}

The XRD analysis shown in Figure 4 (above) confirmed that marble slurry consists of $\mathrm{CaCO}_{3}$ (Calcite), quantified as $98 \%$ according to the STA results Figure 4 (below). It is noticeable that a mass loss occurred between $330-360{ }^{\circ} \mathrm{C}$ due to organic compound 
decomposition, i.e., the resin used for the puttying of marble slates as also identified by FTIR analysis.


Figure 2. SEM micrographs of as-received (above) and ground (below) glass powder.

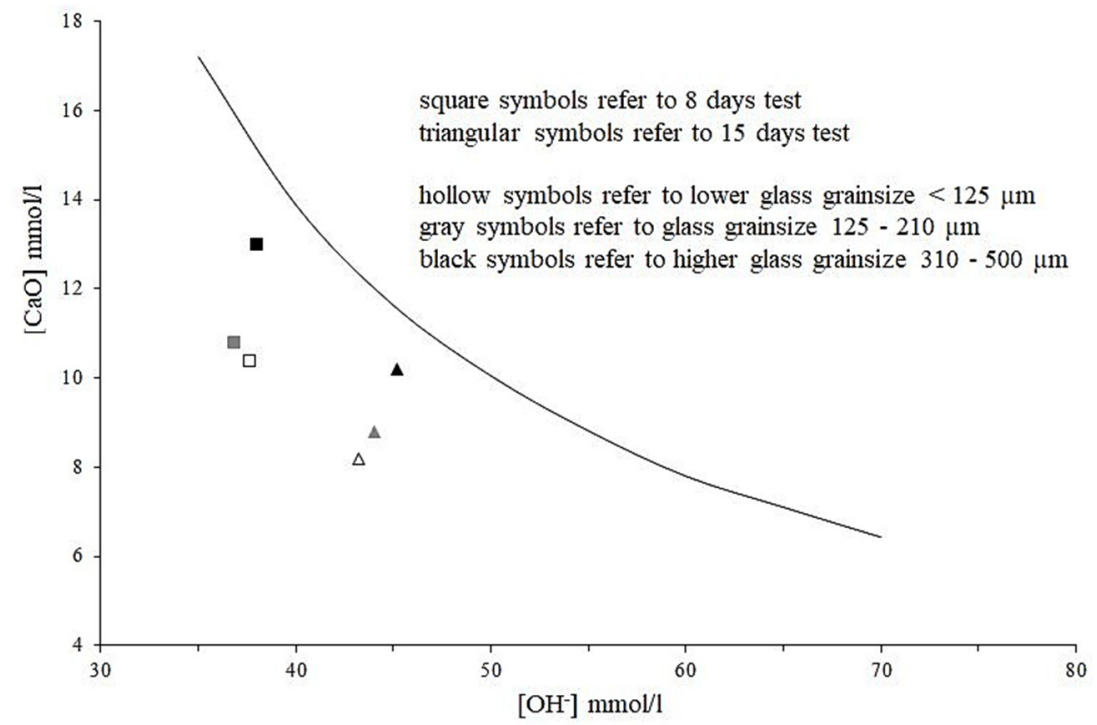

Figure 3. Pozzolanic test results. 

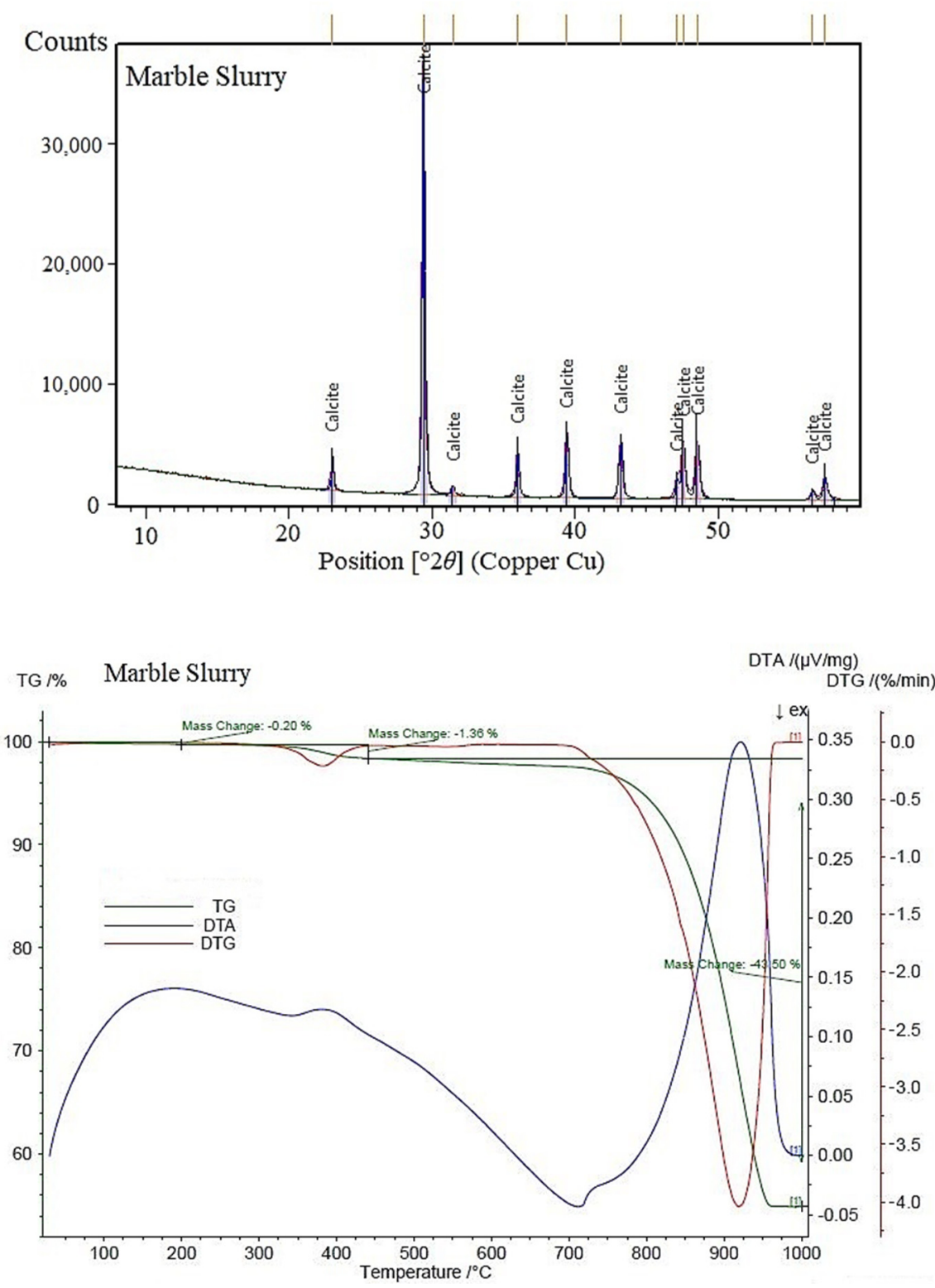

Figure 4. Characterization of marble slurry: XRD pattern (above); STA results (below).

FT-IR analysis, shown in Figure 5, was performed after solvent extraction using ethanol or acetone, and on the residue of dissolution with hydrochloric acid. The latter procedure provided the best results and confirmed that the organic compound was a cured polystyrene resin.

\subsubsection{Kilned Marble Slurry and Slaked Lime}

X-ray diffraction analyses were conducted on the kilned marble slurry and slaked lime (Figure 6).

As expected, XRD patterns highlight the conversion of marble slurry to lime and portlandite after kiln heating and slaking, respectively. STA performed on slaked lime (Figure 7) indicates that after 10 days an almost complete conversion of Calcium Oxide to Calcium Hydroxide occurred. 


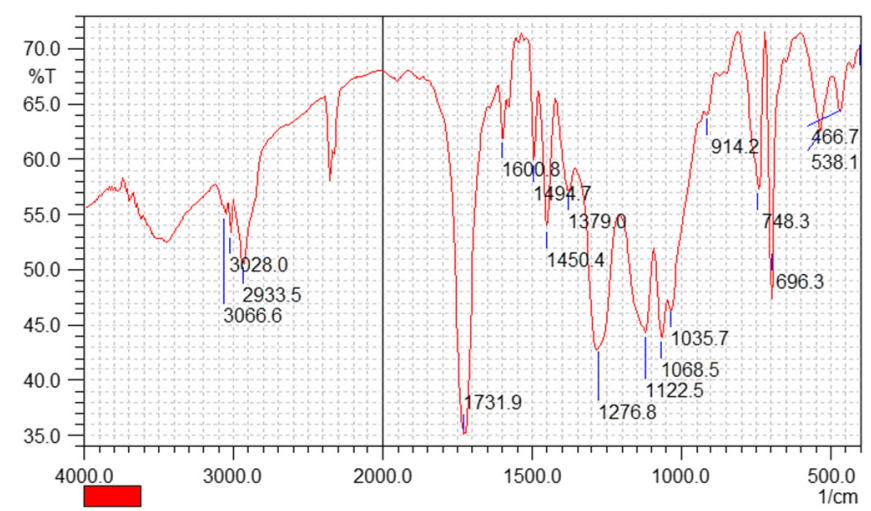

Figure 5. Spectrum of $\mathrm{HCl}$ attack residue from marble (the solvent was $\mathrm{HCl}$ ).
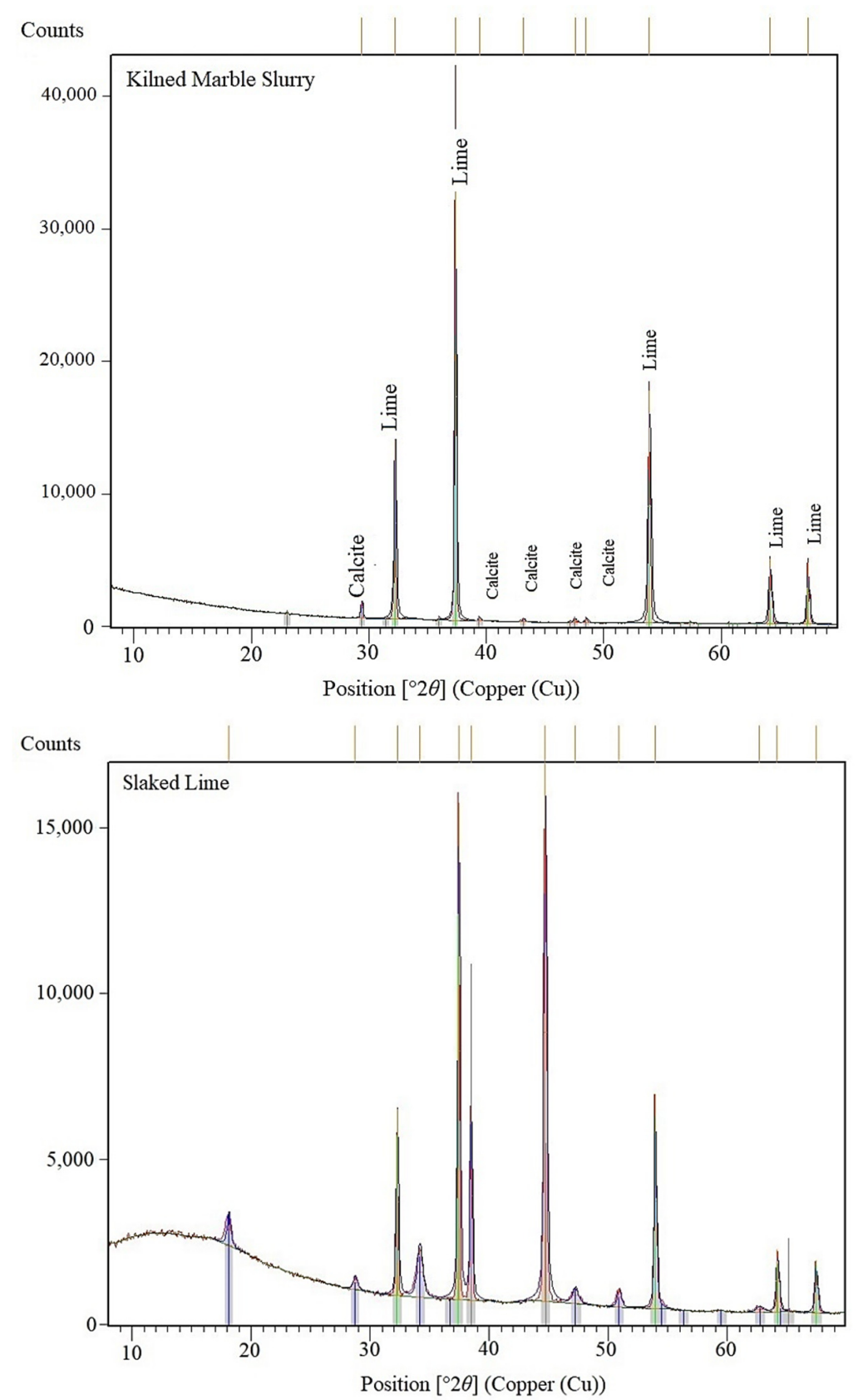

Figure 6. X-Ray diffractograms of kilned marble slurry (above) and slaked lime (below). 


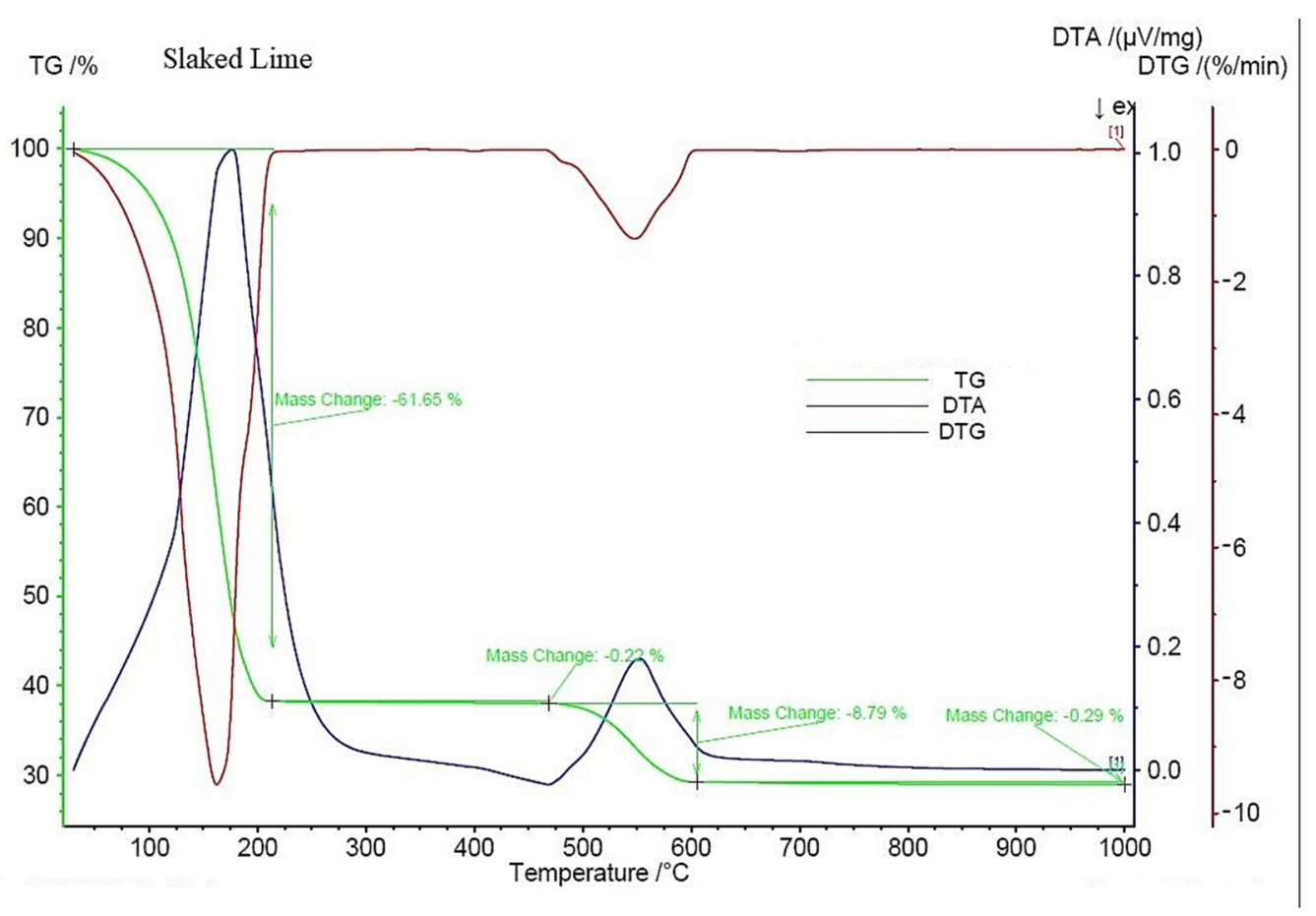

Figure 7. Simultaneous Thermal Analysis (STA) on slaked lime.

The use of a Scanning Electron Microscope (SEM-ESEM) combined with EDS microscopy was performed for kilned marble slurry mixed with water. Figure 8 highlights the predominance of hexagonal crystals and the dimensions of each component:

- Order of tens of microns for the aggregates.

- Under one micron for the crystals.

\subsection{Types of Proposed Mortars}

In this work, nine different types of mortars were prepared. Three were constituted by slaked lime from marble slurry (L), glass powder $(G)$ and river sand (S) in 1:1:1.5 volume ratio with three different glass grain size, i.e., lower than 125 microns (a), between 125 and 210 microns (b) and between 210 and 350 microns (c). Three were composed of Natural Hydraulic Lime $(\mathrm{N})$ with a water to binder weight ratio equal to 0.8 , glass powder $(\mathrm{G})$ and river sand (S) in 1:1:1.5 volume ratio with the three different glass grain sizes as above. The last three were obtained by mixing slaked lime from marble slurry (L) and river sand (S) used in two different fractions; the first characterized by the same grain size distribution of the glass powder in a 1:1 volume ratio with the slaked lime and the second used as received in 1:1.5 volume ratio with the slaked lime. This composition was chosen to reproduce the aggregate grain size distribution of hydraulic mortars in air-hardening mortars. The mortars were named as shown in Table 2, according to the composition.

LGS formulations were aimed at evaluating the reactivity of recycled glass powder with calcium hydroxide $\left(\mathrm{Ca}(\mathrm{OH})_{2}\right)$ as a function of the grain size. The LSS and NGS mixes were prepared with the same composition of the LGS mixes to evaluate the performance of the hydraulic binder compared to air-hardening lime and natural hydraulic lime.

The samples were prepared by mixing the dry powders in a container for at least 2 min to homogenize the constituents, then the slaked lime (for LGS and LSS mortars) or water (for NGS mortars) were added, and the components were further mixed for at least 4 min until a homogeneous and workable mixture was obtained.

The mortars were then put in $40 \times 40 \times 160 \mathrm{~mm}$ molds for the three-point bending and compressive tests according to the standard UNI EN 1015-11 (2013) [40]. The specimens were cured in the molds for five days in laboratory conditions $\left(22 \pm 2{ }^{\circ} \mathrm{C}\right.$ and $\left.50 \pm 5 \% \mathrm{RH}\right)$ in order to allow the samples to reach adequate mechanical properties to facilitate the 
demolding process without causing damages. After five days, the samples were removed from the molds and placed in a climatic chamber at $22 \pm 2{ }^{\circ} \mathrm{C}$ and $90 \pm 5 \% \mathrm{RH}$ for three months. A high relative humidity was chosen to favor hydraulic hardening with respect to air-hardening for the proposed hydraulic binder-based mortars (LGS), while a long curing time (3 months) was chosen to allow the air-lime (LSS) to reach adequate hardening.
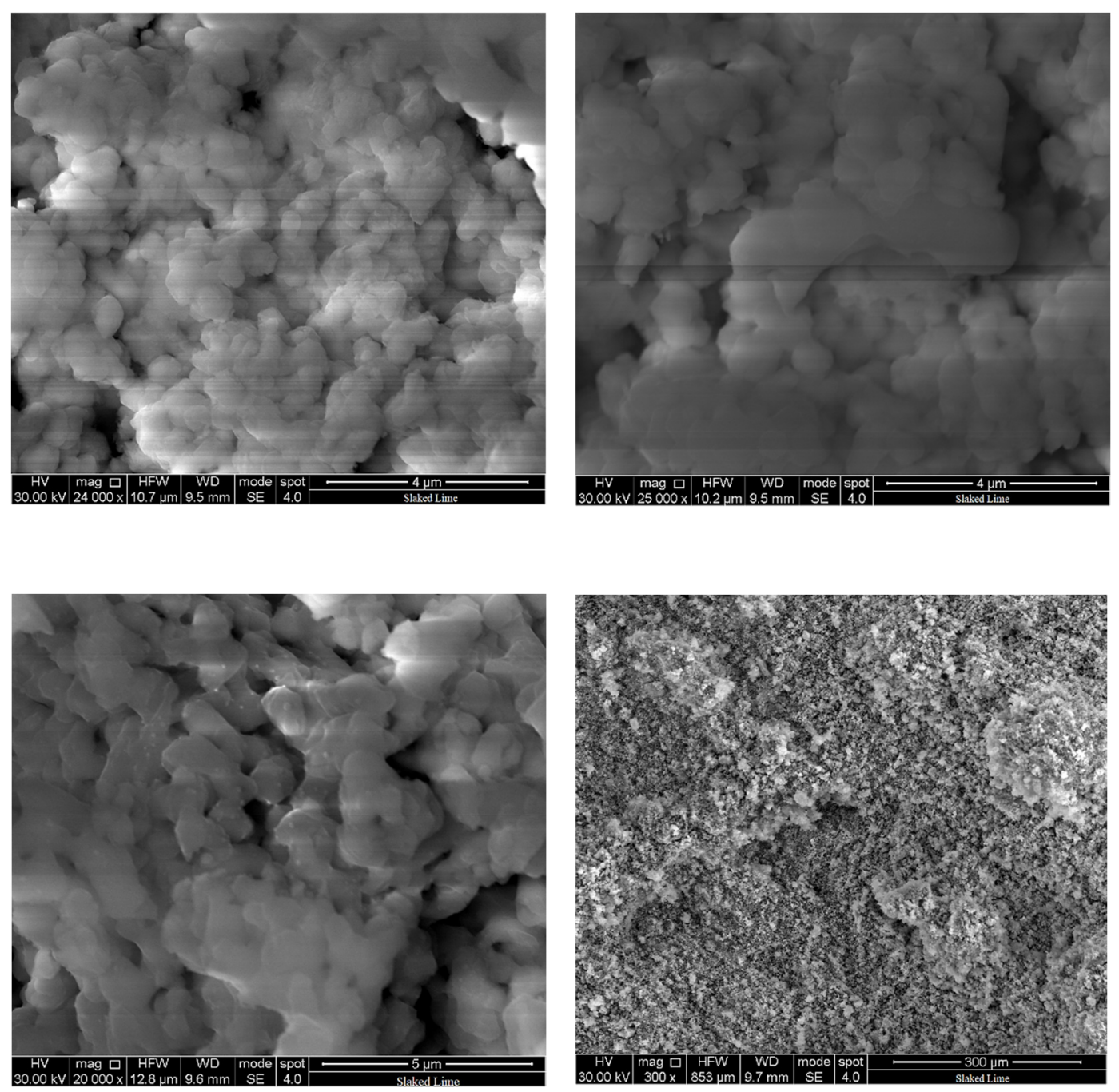

Figure 8. SEM micrographs of slaked lime.

Table 2. Composition by volume of the mortars: $\mathrm{a}=$ lower than $125 \mu \mathrm{m}, \mathrm{b}=125 \div 210 \mu \mathrm{m} ; \mathrm{c}=210 \div 350 \mu \mathrm{m}$.

\begin{tabular}{|c|c|c|c|c|c|c|c|c|c|}
\hline \multirow{2}{*}{$\begin{array}{l}\text { Type of } \\
\text { Mortars }\end{array}$} & \multicolumn{2}{|c|}{ Binder } & \multicolumn{3}{|c|}{ Glass Powder Grain Size } & \multicolumn{3}{|c|}{ River Sand Grain Size } & \multirow{2}{*}{$\begin{array}{c}\text { River Sand } \\
\text { As Received }\end{array}$} \\
\hline & Slaked Lime & NHL 3,5 & $\mathbf{a}$ & $\mathbf{b}$ & c & $\mathbf{a}$ & $\mathbf{b}$ & c & \\
\hline LGS_1 & 1 & & 1 & & & & & & 1.5 \\
\hline LGS_2 & 1 & & & 1 & & & & & 1.5 \\
\hline LGS_3 & 1 & & & & 1 & & & & 1.5 \\
\hline NGS_1 & & 1 & 1 & & & & & & 1.5 \\
\hline NGS_2 & & 1 & & 1 & & & & & 1.5 \\
\hline NGS_3 & & 1 & & & 1 & & & & 1.5 \\
\hline LSS_1 & 1 & & & & & 1 & & & 1.5 \\
\hline LSS_2 & 1 & & & & & & 1 & & 1.5 \\
\hline LSS_3 & 1 & & & & & & & 1 & 1.5 \\
\hline
\end{tabular}




\subsection{Experimental Characterization of the Mortars}

\subsubsection{Three-Point Bending Test}

For each type of mortar, five specimens were tested at 90 days of curing, and the results were recorded as the average and standard deviation of the tensions at breakage obtained from valid tests (at least three specimens for each type). Flexural strength was obtained for each sample by the following equation:

$$
\sigma_{\max }=\frac{3 P L}{2 b h^{2}}
$$

The tests were carried out according to the standard, UNI EN 1015-11 (2013) [40] in force control in a Zwick/Roell Z005 universal electromechanical machine equipped with a $5 \mathrm{kN}$ load cell. The span value was set to $100 \mathrm{~mm}$, the preload to $20 \mathrm{~N}$ and the loading speed to $20 \mathrm{~N} / \mathrm{s}$ in order to obtain the breakage of the specimens between 15 and $60 \mathrm{~s}$.

\subsubsection{Compressive Test}

For each type of mortar, five specimens were tested at 90 days of curing, and the results were recorded as average and standard deviation of the maximum compressive strength obtained from valid tests (at least three specimens for each type). The tests were carried out in force control on halves of the samples previously tested for bending with reference to the standard UNI EN1015-11 [40], in a universal electromechanical machine MP Strumenti Tools WANCE UTM 502, at a loading speed equal to $50 \mathrm{~N} / \mathrm{s}$ to obtain the rupture for all the specimens between 20 and $90 \mathrm{~s}$.

\subsubsection{Porosity Measurement}

For each type of mortar, the apparent densities (from the ratio between the weight and the apparent volume of each specimen) and the real densities (by performing at least two tests of helium picnometry on fragments of samples) were calculated at 90 days of curing. The porosity (or empty index) was evaluated using the following equation:

$$
\text { Porosity }[\%]=100\left(1-\frac{\rho_{\text {app }}}{\rho_{\text {real }}}\right)
$$

\subsubsection{Water Absorption and Desorption Test}

Absorption and desorption tests were conducted at 90 days of curing on at least three specimens for each type of mortar investigated on halves of the samples previously tested for bending, according to the standard UNI EN 1015-18 (2004) [41]. Before performing the water absorption test, the samples were dried in an oven at $60^{\circ} \mathrm{C}$ until constant mass was reached. The samples were then placed in a container with the fracture surface of the prism downward on suitable supports to maximize the contact between the water and the surfaces of the samples. The water level in the container was maintained between 5 and $10 \mathrm{~mm}$ throughout the test, which was performed in laboratory conditions $22 \pm 2{ }^{\circ} \mathrm{C}$ and $50 \pm 5 \% \mathrm{RH}$. The mass of each sample was recorded after 0, 10, $90 \mathrm{~min}$ of immersion, and the absorption coefficient was evaluated by the following equation:

$$
C=0.1\left(M_{2}-M_{1}\right)
$$

where: $C$ is the absorption coefficient, $M_{1}$ is the mass of the sample after $10 \mathrm{~min}$ of immersion and $M_{2}$ is the mass of the sample after $90 \mathrm{~min}$ of immersion. On completion of the test, the specimens were left in the water container until saturation. Water desorption curves were obtained by monitoring at regular intervals $(24 \mathrm{~h})$ the weight loss of the mortars at $22 \pm 2{ }^{\circ} \mathrm{C}$ and $50 \pm 5 \% \mathrm{RH}$. 


\subsubsection{Simultaneous Thermal Analysis (STA)}

Simultaneous thermal analysis was performed using a Netzsch STA 449 Jupiter F1 instrument. The tests were carried out in the $30-1000{ }^{\circ} \mathrm{C}$ range with a heating rate of $10^{\circ} \mathrm{C} / \mathrm{min}$ and nitrogen flux of $20 \mathrm{~mL} / \mathrm{min}$. Thermogravimetry is considered one of the most effective analytical techniques for determining mortar hydraulicity $[42,43]$. Recorded weight losses were labeled according to the temperature range: $30-200{ }^{\circ} \mathrm{C}$ as $\mathrm{H}_{2} \mathrm{O}_{\text {abs }}$; 200-600 ${ }^{\circ} \mathrm{C}$ as $\mathrm{H}_{2} \mathrm{O}_{\text {idr }}$; above $600{ }^{\circ} \mathrm{C}$ as $\mathrm{CO}_{2}$.

\section{Results and Discussion}

\subsection{Thin Sections Observation}

Mortars samples were prepared to produce thin sections for petrographic characterization after one month of hardening. Particularly, thin section observation is a powerful tool to identify the presence of reaction borders between lime and pozzolanic aggregate [44].

Figure 9 shows the presence of small reaction fringes, visible all around some of the glass grains and indicated with red arrows, after only one month of hardening, which was considered a good sign of glass pozzolanic behavior.

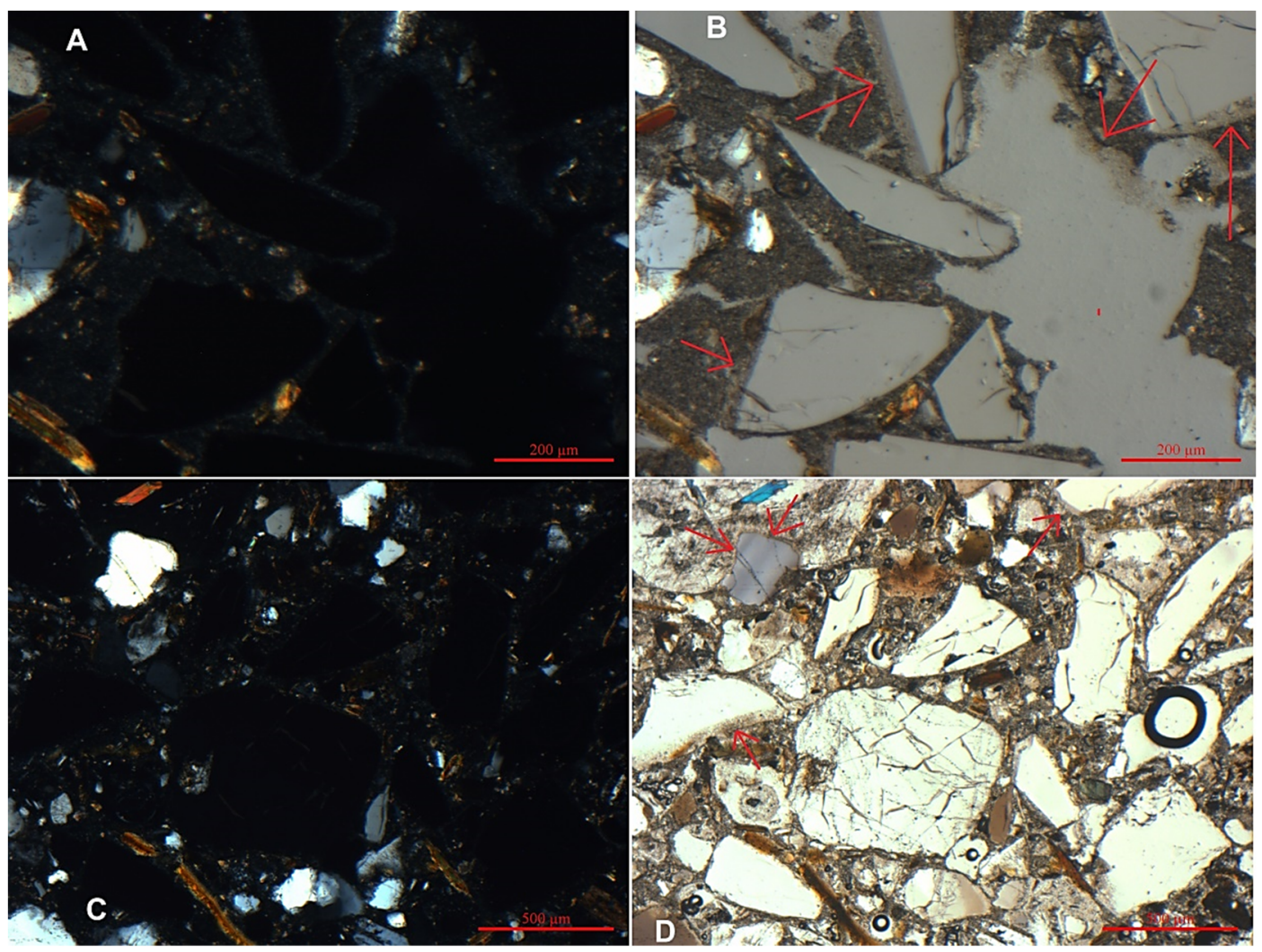

Figure 9. Microscopic images in observations with a crossed-polarized lens, (A,C), and parallel polarized lens, (B,D).

\subsection{Three-Point Bending Test}

The results obtained from the bending tests are shown in Figure 10a. The values of flexural strength of the proposed material (LGS) were clearly higher than those obtained by simple air-hardening lime mortars (LSS), and particularly for the lowest grain size particles, the LGS mortars reached more than half of the NGS mortars. In fact, the effect of the grain size was remarkable, leading to a significant increase in the flexural strength of approximately $100 \%$ between LGS_3 and LGS_1. These results are in agreement with those obtained by $[36,45,46]$ who evidenced an increase in the flexural behavior when recycled glass powder was used in concrete, both in substitution of cement and as a fine aggregate. 


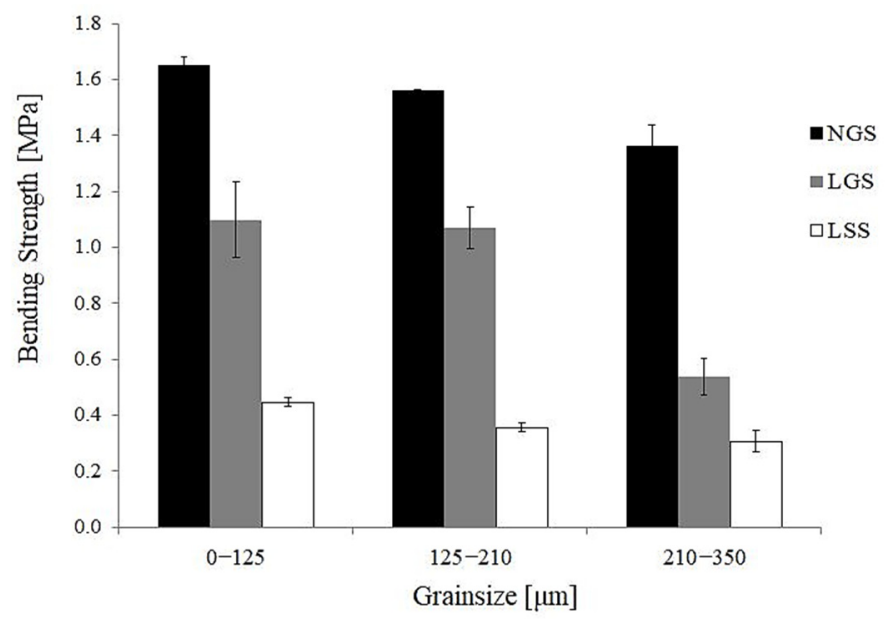

(a)

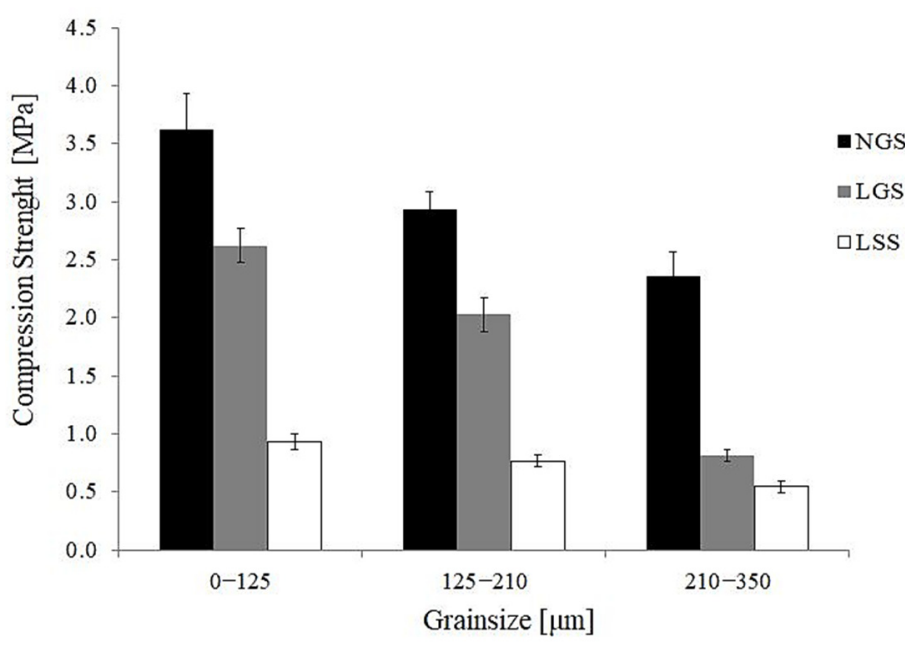

(b)

Figure 10. (a) Three Point Bending, and (b) compression results.

\subsection{Compressive Test}

As obtained for bending, the compressive test results (Figure 10b) showed resistance values of the proposed material (LGS) significantly higher than those exhibited by air lime-based mortars (LGS) and similar to those obtained by natural hydraulic lime-based mortars (NGS). Both compressive and bending results confirmed the higher reactivity of glass with lower particle size; hence, it is preferable to mill the raw material provided by the recycling plant to improve its performance as a pozzolanic additive. It is also important to note that several studies reported that, although early-age strength can be lower compared to the reference when recycled waste glass is used in concrete, later-age strength may increase $[47,48]$. For this reason, it is plausible to expect that the compressive strength of the LGS mortars at later curing times may further increase not only for the progress of the carbonation process but also for the continuation of the pozzolanic reactions between the glass powders and the residual portlandite.

\subsection{Porosity Test}

From the data reported in Table 3, it can be assessed that LGS mortars are characterized by higher porosity compared to natural hydraulic lime-based mortars (NGS). This can be a sign of prospective better thermal insulation performance, which can further reduce the operating costs of these plasters. 
Table 3. Porosity of samples calculated by density measurements.

\begin{tabular}{lcc}
\hline & Grain Size $[\mu \mathrm{m}]$ & Porosity $[\%]$ \\
\hline \multirow{3}{*}{ NGS } & $0-125$ & 32 \\
\cline { 2 - 3 } & $125-210$ & 32 \\
\cline { 2 - 3 } & $210-350$ & 33 \\
\hline \multirow{2}{*}{ LGS } & $0-125$ & 37 \\
\cline { 2 - 3 } & $125-210$ & 37 \\
\hline \multirow{2}{*}{ LSS } & $210-350$ & 38 \\
\hline & $0-125$ & 35 \\
\hline & $125-210$ & 34 \\
\hline
\end{tabular}

\subsection{Water Absorption and Desorption Test}

The results for absorption coefficients are reported in Figure 11. The lowest values were once again reached for LGS_a and LGS_b mortars. In this case, performances were even higher than for NGS samples, which confirms the possibility of using the LGS mortars in place of NGS for civil engineering.

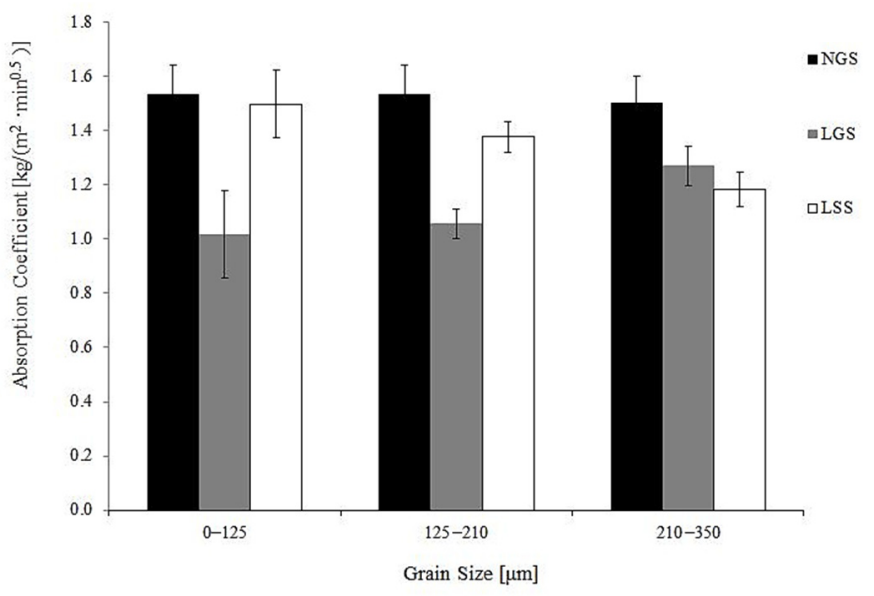

Figure 11. Water absorption coefficient results.

Data obtained for porosity and water absorption coefficients were confirmed by the water absorption and desorption curves (Figures 12 and 13), which revealed slower absorption and faster evaporation of water for the LGS samples compared to the NGS samples. The lower water absorption coefficient of the LGS mortars could be due to the higher average dimensions of the pores compared to the air lime mortars, leading to a slower water absorption rate due to capillary action. This hypothesis was validated by observing water absorption curves showing that after $24 \mathrm{~h}$ the mortars LGS125 and LGS210 did not reach saturation, unlike the other mortars. This property could be considered the main advantage for manufacturing plasters.

\subsection{Simultaneous Thermal Analysis}

By comparing the results of the Simultaneous Thermal Analysis in Figure 14 it is possible to assess the hydraulicity of LGS mortars. In particular, that the weight loss associated with the presence of calcium hydroxide relative to the LSS mortars was considerably higher than that which occurred for LGS mortars. This is because the glass powder used as aggregate reacts with lime to produce a calcium silicate hydrate. Furthermore, the effect of grain size on the reactive efficiency of the glass powder was evident since lower values 
of the calcium hydroxide peak were recorded at lower granulometry due to the higher surface/volume ratio of the particles.

According to [43], the classification of mortar hydraulicity can be performed more effectively by dividing the value of $\mathrm{CO}_{2}$ and $\mathrm{H}_{2} \mathrm{Oidr}$ associated weight loss by absorbed water, $\mathrm{H}_{2}$ Oabs. The resulting graph in Figure 15 , clearly shows the different hydraulic behavior of LGS mortars compared to LSS mortars, as the representing points of the LGS are closer to NHL mortars ones.

The mechanical performances were in good agreement with the thermogravimetric characterization, as clearly shown in Figure 16.

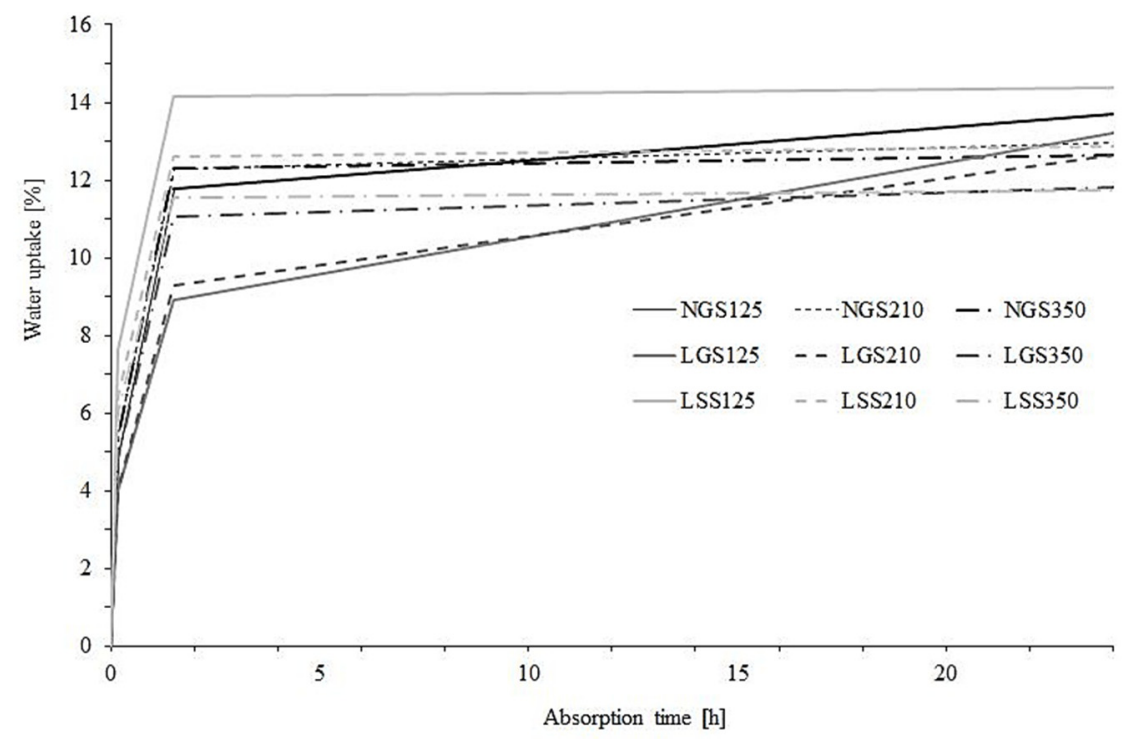

Figure 12. Water absorption curves.

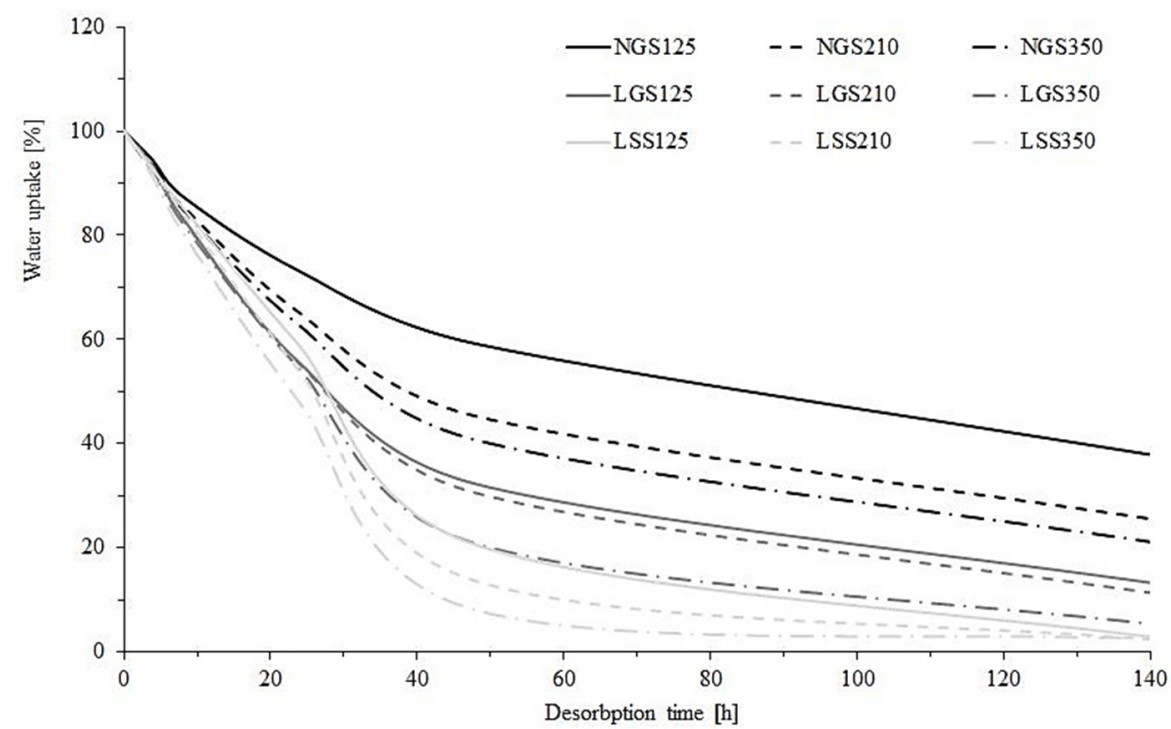

Figure 13. Water desorption curves. 


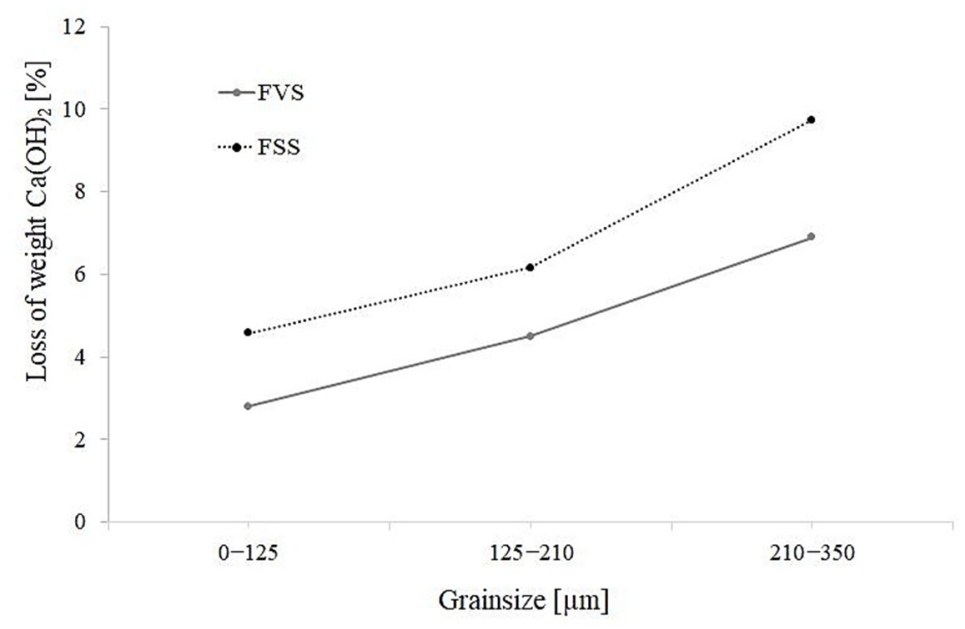

Figure 14. Weight loss associated with portlandite obtained from STA.

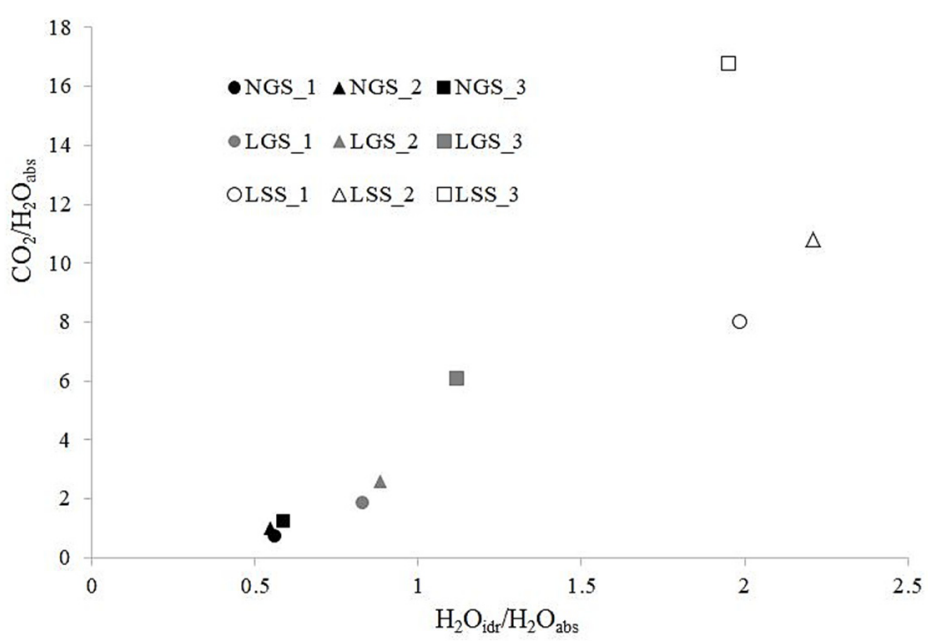

Figure 15. Correlation between carbon dioxide and hydraulic water obtained from STA.

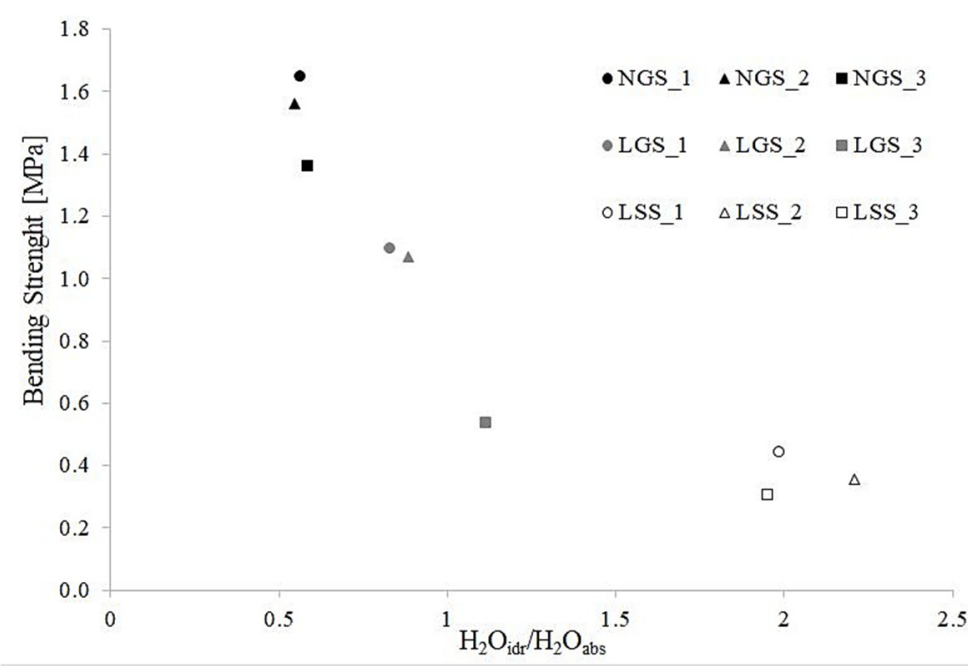

Figure 16. Correlation between bending strength and hydraulic water.

\section{Conclusions}

This work proposes a more sustainable binder produced using wastes as raw materials, reducing the environmental issues of both binder production and waste disposal. 
The preliminary characterization of the materials revealed the opportunity to use marble slurry to produce an air-hardening lime that can act as a hydraulic binder when mixed with glass powder obtained from urban waste collection. Thermal analysis and microscopic observation confirmed the hydraulic behavior of the binder. Moreover, mechanical tests clearly showed good mechanical performance of the hydraulic binder based on air-hardening lime with better performance at lower grain size of the glass powder. Particularly, mechanical properties of mortars with fine glass powder were considerably higher than air-hardening mortars, while the differences were reduced using coarser glass particles.

It is fundamental to note that pozzolanic behavior of the glass powder could be obtained if the fineness did not exceed $210 \mu \mathrm{m}$. The experimental data showed that this system, which exploits the coupling of two waste materials, their transformation and combined use, can be used to obtain mortars with high mechanical performance. Finally, the proposed mortars showed higher porosity compared to natural hydraulic lime mortars, and comparable mechanical properties. These results indicate that these kinds of mortars may offer a further advantage related to their better insulating properties.

\section{Patents}

The content is object of Italian Patent Application No. 102018000007810 filed on 3 August 2018.

Author Contributions: Conceptualization, B.M. and A.V.; methodology, B.M. and D.B.; validation, B.M., D.B. and A.V.; formal analysis, B.M. and D.B.; investigation, B.M., D.B. and C.S.; resources, B.M. and A.V.; data curation, B.M., D.B. and C.S.; writing —original draft preparation, D.B.; writingreview and editing, D.B. and B.M.; supervision, A.V.; project administration, A.V. All authors have read and agreed to the published version of the manuscript.

Funding: This research received no external funding.

Data Availability Statement: All data is contained within the article.

Conflicts of Interest: The authors declare no conflict of interest.

\section{References}

1. Kabeer, K.I.S.A.; Vyas, A.K. Experimental investigation on utilization of dried marble slurry as fine aggregate in lean masonry mortars. J. Build. Eng. 2019, 23, 185-192. [CrossRef]

2. Ashish, D.K. Feasibility of waste marble powder in concrete as partial substitution of cement and sand amalgam for sustainable growth. J. Build. Eng. 2018, 15, 236-242. [CrossRef]

3. Rana, A.; Kalla, P.; Csetenyi, L.J. Sustainable use of marble slurry in concrete. J. Clean. Prod. 2015, 94, 304-311. [CrossRef]

4. Ulubeylia, G.C.; Artir, R. Properties of Hardened Concrete Produced by Waste Marble Powder. Procedia Soc. Behav. Sci. 2015, 195, 2181-2190. [CrossRef]

5. Aliabdo, A.A.; Elmoaty, M.A.; Auda, E.M. Re-use of waste marble dust in the production of cement and concrete. Constr. Build. Mater. 2014, 50, 28-41. [CrossRef]

6. Corinaldesi, V.; Moriconi, G.; Naik, T.R. Characterization of marble powder for its use in mortar and concrete. Constr. Build. Mater. 2010, 24, 113-117. [CrossRef]

7. Aruntas, H.Y.; Guru, M.; Dayi, M.; Tekin, I. Utilization of waste marble dust as an additive in cement production. Mater. Des. 2010, 31, 4039-4042. [CrossRef]

8. Sutcu, M.; Alptekin, H.; Erdogmus, E.; Er, Y.; Gencel, O. Characteristics of fired clay bricks with waste marble powder addition as building materials. Constr. Build. Mater. 2015, 82, 1-8. [CrossRef]

9. Sobolev, K.; Türker, P.; Soboleva, S.; Iscioglu, G. Utilization of waste glass in ECO cement, strength properties and microstructural observations. J. Waste Manag. 2006, 27, 971-976. [CrossRef] [PubMed]

10. Shi, C.; Zheng, K. A review on the use of waste glasses in the production of cement and concrete. Resour. Conserv. Recycl. 2007, 52, 234-247. [CrossRef]

11. Shekhawat, B.S.; Aggarwal, D.V. Utilisation of Waste Glass Powder in Concrete-A Literature Review. Int. J. Innov. Res. Sci. Eng. Technol. 2014, 3, ISSN: 2319-8753.

12. Fragata, A.; Paiva, H.; Velosa, A.L.; Veiga, M.R.; Ferreira, V.M. Application of Crushed Glass Residues in Mortars, Sustainable Construction, Materials and Practices: Challenge of the Industry for the New Millennium; Portugal, S.B., Ed.; IOS Press: Amsterdam, The Netherlands, 2007. 
13. Edwards, D.D.; Allen, G.C.; Ball, R.J.; El-Turki, A. Pozzolanic properties of glass fines in lime mortars. Adv. Appl. Ceram. 2007, 106, 309-313. [CrossRef]

14. Omran, A.; Tagnit-Hamou, A. Performance of glass-powder concrete in field applications. Constr. Build. Mater. 2016, 109, 84-95. [CrossRef]

15. Ramdani, S.; Guettala, A.; Benmalek, M.L.; Aguiar, J.B. Physical and mechanical performance of concrete made with waste rubber aggregate, glass powder and silica sand powder. J. Build. Eng. 2019, 21, 302-311. [CrossRef]

16. Olivera, R.; de Brito, J.; Veiga, R. Reduction of the cement content in rendering mortars with fine glass aggregates. J. Clean. Prod. 2015, 95, 75-88. [CrossRef]

17. Penacho, P.; de Brito, J.; Veiga, M.R. Physico-mechanical and performance characterization of mortars incorporating fine glass waste aggregates. Cem. Concr. Compos. 2014, 50, 47-59. [CrossRef]

18. Paul, S.C.; Savija, B.; Babafemi, A.J. A comprehensive review on mechanical and durability properties of cement-based materials containing waste recycled glass. J. Clean. Prod. 2018, 198, 891-906. [CrossRef]

19. Togrul Tunc, E. Recycling of marble waste: A review based on strength of concrete containing marble waste. J. Environ. Manag. 2019, 231, 86-97. [CrossRef] [PubMed]

20. Yoshizawa, S.; Tanaka, M.; Shekdar, A.V. Global trends in waste generation. In Recycling, Waste Treatment and Clean Technology; Gaballah, I., Mishar, B., Solozabal, R., Tanaka, M., Eds.; TMS Mineral, Metals and Materials Publishers: Madrid, Spain, 2004; pp. 1541-1552.

21. Pappu, A.; Saxena, M.; Asolekar, S.R. Solid wastes generation in India and their recycling potential in building materials. Build. Environ. 2007, 42, 2311-2320. [CrossRef]

22. Hanle, L.; Jayaraman, K.; Smith, J. $\mathrm{CO}_{2}$ Emissions Profile of the US Cement Industry. Available online: https:/ / www3.epa.gov / ttnchie1/conference/ei13/ghg/hanle.pdf (accessed on 6 June 2021).

23. Ali, M.B.; Saidur, R.; Hossain, M.S. A review on emission analysis in cement industries. Renew. Sustain. Energy Rev. 2011, 15, 2252-2261. [CrossRef]

24. Rizzo, G.; D'Agostino, F.; Ercoli, L. Problems of soil and groundwater pollution in the disposal of "marble" slurries in NW Sicily. Environ. Geol. 2008, 55, 929-935. [CrossRef]

25. Halbert, G.; Billard, C.; Rossi, P.; Chen, C.; Roussel, N. Cement production technology improvement compared to factor 4 objectives. Cem. Concr. Res. 2010, 40, 820-826. [CrossRef]

26. Gartner, E. Industrially interesting approaches to "low- $\mathrm{CO}_{2}$ " cements. Cem. Concr. Res. 2004, 34, 1489-1498. [CrossRef]

27. Al-Fakih, A.; Mohammed, B.S.; Liew, M.S.; Nikbakht, E. Incorporation of waste materials in the manufacture of masonry bricks: An update review. J. Build. Eng. 2019, 21, 37-54. [CrossRef]

28. Munir, M.J.; Abbas, S.; Nehdi, M.L.; Kazmi, S.M.S.; Khitab, A. Development of Eco-Friendly Fired Clay Bricks Incorporating Recycled Marble Powder. J. Mater. Civ. Eng. 2018, 30, 04018069. [CrossRef]

29. Bilgin, N.; Yeprem, H.A.; Arslan, S.; Bilgin, A.; Günay, E.; Marşoglu, M. Use of waste marble powder in brick industry. Constr. Build. Mater. 2012, 29, 449-457. [CrossRef]

30. Idir, R.; Cyr, M.; Tagnit-Hamou, A. Role of the nature of reaction products in the differing behaviours of fine glass powders and coarse glass aggregates used in concrete. Mater. Struct. 2012, 46, 233-243. [CrossRef]

31. Starinieri, V.; Illingworth, J.M.; Hughes, D. Use of supplementary aggregates in mortars produced using a novel lime drying technique. Proc. Inst. Civ. Eng. Constr. Mater. 2019, 172, 305-313. [CrossRef]

32. Matos, A.M.; Sousa-Coutinho, J. Durability of mortar using waste glass powder as cement replacement. Constr. Build. Mater. 2012, 36, 205-215. [CrossRef]

33. Papadakis, V.G.; Tsimas, S. Supplementary cementing materials in concrete Part I: Efficiency and design. Cem. Concr. Res. 2002, 32, 1525-1532. [CrossRef]

34. Degirmenci, N.; Yilmaz, A.; Cakir, O.A. Utilization of waste glass as sand replacement in cement mortar. Indian J. Eng. Mater. Sci. 2011, 18, 303-308.

35. Rajabipour, F.; Maraghechi, H.; Fischer, G. Investigating the Alkali-Silica Reaction of Recycled Glass Aggregates in Concrete Materials. J. Mater. Civ. Eng. 2010, 22, 1201-1208. [CrossRef]

36. Ali, E.E.; Al-Tersawy, S.H. Recycled glass as a partial replacement for fine aggregate in self compacting concrete. Constr. Build. Mater. 2012, 35, 785-791. [CrossRef]

37. UNI 11471:2013. Beni Culturali_Valutazione Della Pozzolanicità di un Materiale-Metodo Chimico (Saggio di Pozzolanicità); Ente Nazionale Italiano di Unificazione: Milan, Italy, 2013.

38. Lee, H.; Hanif, A.; Usmand, M.; Sime, J.; Oh, H. Performance evaluation of concrete incorporating glass powder and glass sludge wastes as supplementary cementing material. J. Clean. Prod. 2018, 170, 683-693. [CrossRef]

39. Jani, Y.; Hogland, W. Waste glass in the production of cement and concrete-A review. J. Environ. Chem. Eng. 2014, 2, 1767-1775. [CrossRef]

40. UNI EN 1015-11. Metodi di Prova per Malte per Opere Murarie_Parte 11: Determinazione Della Resistenza a Flessione e a Compressione Della Malta Indurita; Ente Nazionale Italiano di Unificazione: Milan, Italy, 2007.

41. UNI EN 1015-18. Metodi di Prova per Malte per Opere Murarie-Determinazione del Coefficiente di Assorbimento D'acqua per Capillarità Della Malta Indurita; Ente Nazionale Italiano di Unificazione: Milan, Italy, 2004. 
42. Moropoulou, A.; Bakolas, A.; Bisbikou, K. Investigation of the technology of historic mortars. J. Cult. Herit. 2000, 1, 45-58. [CrossRef]

43. Rizzo, G.; Megna, B. Characterization of hydraulic mortars by means of simultaneous thermal analysis. J. Therm. Anal. Calorim. 2008, 92, 173-178. [CrossRef]

44. Rizzo, G.; Ercoli, L.; Megna, B.; Parlapiano, M. Characterization of mortars from ancient and traditional water supply systems in Sicily. J. Therm. Anal. Calorim. 2008, 92, 323-330. [CrossRef]

45. Ismail, Z.Z.; Al-Hashmi, E.A. Recycling of waste glass as a partial replacement for fine aggregate in concrete. Waste Manag. 2009, 29, 655-659. [CrossRef]

46. Parghi, A.; Alam, M.S. Physical and mechanical properties of cementitious composites containing recycled glass powder (RGP) and styrene butadiene rubber (SBR). Constr. Build. Mater. 2016, 104, 34-43. [CrossRef]

47. Du, H.; Tan, K.H. Properties of high volume glass powder concrete. Cem. Concr. Compos. 2017, 75, 22-29. [CrossRef]

48. Kamali, M.; Ghahremaninezhad, A. Effect of glass powders on the mechanical and durability properties of cementitious materials. Constr. Build. Mater. 2015, 98, 407-416. [CrossRef] 